Volume 2 Issue 2, July-December 2021: pp.123-136.

Faculty of Law, Universitas Lampung, Bandar Lampung, Indonesia. http://jurnal.fh.unila.ac.id/index.php/ip

P-ISSN: 2723-2638 E-ISSN: 2745-9314

\title{
Law Enforcement Obstacle Against Online Gambling at Lampung Regional Police
}

\author{
Andri Wetson. R \\ Anugrah Ltd., Indonesia \\ andriwetsonrumahorbo10@gmail.com
}

Submitted: Jan 15, 2021; Reviewed: Feb 4, 2021; Accepted: Apr 5, 2021

Article's Information
keywords:
Criminal act; Law Enforcement;
Online Gambling.

DOI :

https://doi.org/10.25041/ip.v2i2.2232
Easy access to the world of information technology currently impacts the rise of cybercrime, including the crime of online gambling. Many efforts have been made by the government and law enforcers, including, in this case, the police, to prevent and take action against this online gambling crime, either block sites that are gambling arenas or improve the national security system to stop these gambling sites. This research aims to look at law enforcement against online gambling crimes in Bandar Lampung City and determine the factors that became an obstacle in law enforcement of online gambling crimes at Lampung Regional Police. This research method uses a normative juridical approach. Based on the discussion and research results, law enforcement against online gambling crimes in Bandar Lampung City is carried out by applying the instrument of Article 303 of the Criminal Code rather than Article 27 Paragraph (2) Jo. Article 45 of the ITE Law. The research also shows the factors that became an obstacle in law enforcement of online gambling crimes at Lampung Regional Police are: (1) Longer Detention Period for Online Gambling Crimes in the Criminal Code Instruments than the Gambling Control Act, (2) Lack of Investigators' Awareness in Information Technology, (3) Use of Electronic Evidence Requires Expert Information is inhibiting law enforcement against online gambling crimes in Bandar Lampung. Suggestions from the research are to conduct information technology guidance training to the Bandar Lampung Police Investigation and Criminal Unit. 


\section{A. Introduction}

The progress of science and technology that is overgrowing has brought so many impacts and changes in human life. As a result of advances in science and technology, globalization provides excellent benefits for human life worldwide. Therefore, with the development of increasingly sophisticated technology, online games have experienced very rapid development. Online games are mushrooming in big cities and have penetrated small towns, including the countryside. Online games that were initially just a game were later developed into a game that can make money or online gambling. The presence of online gambling games as a negative technological development in the electronic field needs to be addressed from various angles because the impact is returned. As in the use of body-worn cameras abroad, it can reduce citizen complaints and the use of police force but have no significant impact on the activities or policies of officers. ${ }^{1}$

Gambling is a crime that almost all circles of ordinary people do, from low to high economic circles and from parents to children. Following today's developments, gambling crimes are carried out online. ${ }^{2}$ The media has been paying attention to the possibility of predictive policing systems having different effects in exacerbating social injustice. ${ }^{3}$ Gambling crimes, usually carried out using tools or goods, can now be carried out through existing network media or the internet. Using a set of networks such as a computer complete with internet facilities connected to other computers, people can access websites that already contain games which are a means for gambling. ${ }^{4}$ With a critical approach, it is possible to understand how the legal profession responds to the complexity of problems and other different social forces. ${ }^{5}$

The crime of online gambling has developed in people's lives in the current era because participating in online gambling is considered an effortless thing to access. So that gambling can be done anywhere without looking for a quiet place compared to direct gambling, it must be played far from the reach of the surrounding people so as not to be caught. This makes online gambling very attractive to gambling players because they do not have to look for opponents, but opponents always wait a lot in cyberspace. The number of sites for online gambling users on the internet is very easy to access, for example, sbobet, bet 365 , bet 88 , online poker, online lottery, and others. Whereas if law enforcement is disguised in the form of law, the assessment will still decide on individual examples of the ongoing collective conflict. ${ }^{6}$

As the capital of Lampung Province and one of the big cities in Indonesia, Bandar Lampung City certainly does not escape the crime of online gambling. ${ }^{7}$ Gambling is a voluntary bet, risking a value or something that is considered valuable by being aware of certain risks and

\footnotetext{
${ }^{1}$ Anthony A. Braga et al., "Measuring the Direct and Spillover Effects of Body Worn Cameras on the Civility of Police-Citizen Encounters and Police Work Activities," Journal of Quantitative Criminology 36, no. 4 (1 December 2020): 851-76, https://doi.org/10.1007/s10940-019-09434-9.

${ }^{2}$ Hendri Saputra Manalu, "Penegakan Hukum Terhadap Pelaku Tindak Pidana Perjudian Online Penegakan Hukum Terhadap Pelaku Tindak Pidana Perjudian Online (Studi Putusan Pengadilan Negeri Medan Nomor 870/Pid.B/2018/PN.Mdn)," Journal of Education, Humaniora and Social Sciences (JEHSS) 2, no. 2 (September 17, 2019): 428-539, https://ocs.unud.ac.id/index.php/kerthawicara/article/view/46728.

3 Kiana Alikhademi et al., "A Review of Predictive Policing from the Perspective of Fairness," Artificial Intelligence and Law, April 15, 2021, 1-17, https://doi.org/10.1007/s10506-021-09286-4.

${ }^{4}$ Hendri Saputra Manalu, "Penegakan Hukum Terhadap Pelaku Tindak Pidana Perjudian Online (Studi Putusan Pengadilan Negeri Medan Nomor 870/Pid.B/2018/PN.Mdn)," Journal of Education, Humaniora and Social Sciences (JEHSS) 2, no. 2 (December 19, 2019): 428-539, https://doi.org/10.34007/jehss.v2i2.102.

${ }^{5}$ Salvatore Caserta, "The Sociology of the Legal Profession in the Digital Age," International Journal of the Legal Profession, 2021, 1-16, https://doi.org/10.1080/09695958.2021.1920417.

6 Rafał Mańko, "Judicial Decision-Making, Ideology and the Political: Towards an Agonistic Theory of Adjudication," Law and Critique, 30 March 2021, 1-20, https://doi.org/10.1007/s10978-021-09288-w.

7 Dian Eka Safitri, "PENEGAKAN HUKUM TERHADAP PELAKU PERJUDIAN ONLINE DI KOTA MAKASSAR," Jurnal Magister Hukum ARGUMENTUM 7, no. 1 (April 1, 2020): 10, https://doi.org/10.24123/argu.v7i1.3014.
} 
expectations in various game events, matches, competitions, and events that have no or uncertain outcome. The police have implemented urgent public policies with implications for police relations and equitable access to justice. ${ }^{8}$ One example of the case that attracted the author in this article was related to the perpetrator's arrest with the initial L, who was suspected of being an online lottery bookie by the Sub-Directorate III of Direktorat Reserse Kriminal Umum (Ditreskrimum) Officer of the Lampung Police in the Gedung Pakuon Village, South Teluk Betung District. This online gambling case was revealed when the police confiscated evidence in laptops and sheets recorded by lottery installers. This lottery gambling developed in various regions, including in Bandar Lampung. This can be identified from the cases of lottery gamblers where the perpetrator is a woman.

In line with the above case, the author sees that easy access to the world of information technology currently impacts the rise of cybercrime, including the crime of online gambling. A lot of efforts have been taken by the government and law enforcers, including, in this case, the police. To prevent and take action against this online gambling crime, either block sites that are gambling arenas or improve the national security system to stop these gambling sites. ${ }^{9}$ Based on the results of previous studies, it has been found that the characteristics of online gambling users are based on age. Almost half are aged 15-17 years (30\%) and those aged 18-21 years (70\%). Ages 18-21 years are much interested in using online gambling games than children aged 15-17 years. Online gambling is contrary to legal norms, decency, customs, and religion in the Indonesian nation. ${ }^{10}$ Therefore, it is essential to overcome online gambling. There are many efforts taken by the government and law enforcers to prevent and take action against this online gambling crime, either by closing the gambling arenas or improving the national security system to block gambling sites to create a sense of security and social inequality in the community, especially in Bandar Lampung area.

The approach method used in this study uses an empirical juridical approach, where an empirical juridical approach is an approach that examines secondary data first and then continues by conducting primary data research in the field to obtain a better understanding and provide the most precise possible explanation of the legal materials presented and juridical activities in the reality of society. ${ }^{11}$ Problems of the research are; how is the law enforcement towards online gambling crimes in Bandar Lampung? What are law enforcement's obstacles against online gambling crimes in Bandar Lampung?

\section{B. Discussion}

\section{Law Enforcement towards Online Gambling Crimes in Bandar Lampung}

The problem of online gambling is increasingly worrying among the public. Online gambling, which is not seen directly by the community, causes problems that are sometimes difficult to contain due to soccer gambling and online poker using information technology. ${ }^{12}$ This is a form of the development of crime with the mode of using modern or electronic transactions. In terms

\footnotetext{
${ }^{8}$ Keller G. Sheppard, Gregory M. Zimmerman, and Emma E. Fridel, "Examining the Relevance of Contextual Gun Ownership on Fatal Police Shootings," Justice Quarterly, 24 May 2021, 1-23, https://doi.org/10.1080/07418825.2021.1922733.

${ }^{9}$ Enik Isnaini, "TINJAUAN YURIDIS NORMATIF PERJUDIAN ONLINE MENURUT HUKUM POSITIF DI INDONESIA,” Jurnal Independent 5, no. 1 (June 1, 2017): 23, https://doi.org/10.30736/ji.v5i1.61.

10 Gede Darma Sannyasa and I Ketut Mertha, "PENGATURAN TINDAK PIDANA PERJUDIAN DAN PERTANGGUNGJAWBAN PIDANA KORPORASI DALAM MICRO-TRANSACTION PADA GAME ONLINE," Kertha Semaya: Journal Ilmu Hukum 8, no. 9 (September 24, 2020): 1467-82, https://doi.org/10.24843/KS.2020.v08.i09.p14.

${ }^{11}$ Alimuddin, “Aplikasi Pembaharuan Hukum Dalam Teori Socio Legal Studies,” Ditjen Badan Peradilan, 2004, www.badilag.net.

${ }^{12}$ Wella Haryanti, "Penegakan Hukum Oleh Satreskrim Kepolisian Resort Kota Padang Terhadap Pelaku Tindak Pidana Perjudian Yang Dilakukan Oleh Remaja," Article Wisudawan 12, no. 2 (2020): 27-37, https://www.ejurnal.bunghatta.ac.id/index.php/JFH/article/view/18198.
} 
of the ITE Law, the regulation on gambling criminal offenses is contained in Article 27 Paragraph (2), which reads: "each person that intentionally and without rights, distributes and/or transmits and/or makes accessible Electronic Information and/or Electronic Documents that have gambling payload".

Gambling is contained in Article 303 of the Criminal Code and Law No. 7 of 1974 concerning Gambling Control. ${ }^{13}$ In Article 1 of Law no. 7 of 1974 concerning Gambling Control, gambling is declared a crime. The act of online gambling in today's era using technology has progressed and is advanced. ${ }^{14}$ Examples of gambling that follows technological developments are poker, soccer, and online qiuqiu gambling. There are no longer limitations of space and time through online gambling, and it is easier to gamble as long as the gambling crimes perpetrators are skilled in information technology. ${ }^{15}$

The use of the instruments of the Criminal Code and the ITE Law was used by investigators of the Sub-unit Deputy Control of the Criminal Investigation Unit of the Bandar Lampung Police to uncover online gambling rampant in Bandar Lampung. Based on Table 1 in the previous chapter, online gambling, in general, is handled by investigators accordingly to Article 303 of the Criminal Code, not Article 27 Paragraph (2) of the ITE Law. Solved case files since 2015 s.d. 2017 are 17 (seventeen) files. In 2015, there were 4 (four) files. In 2016, there were 5 (five) files, and in 2017 there were 8 (eight) files. These cases indicate an increase every year because the modus operandi of online gambling is highly in demand by Bandar Lampung's society, especially those who are under the direct authority of the Bandar Lampung Police. The motive of online gamblers is to increase their income, and most of them have unclear jobs, which leads them to choose online gambling as a profession. ${ }^{16}$ According to Eko Wijaya, as the VC Committee of the Bandar Lampung Police Satreskrim, Bandar Lampung Police have several methods to discover online gambling activities in the jurisdiction of the Bandar Lampung Police. As follows:

\section{a. Receiving Reports of Public Complaints}

The police's initial step in taking action was from public complaints reports that it was known that there were acts of online game gambling. Furthermore, the community members informed the actual events to the Police investigators experienced and directed directly in front of the investigators related to online gambling cases. In the community report, investigators will follow up on the investigation process. After the witnesses and evidence are found, then the police will continue the case to the level of investigation and investigation. ${ }^{17}$

\section{b. Conducting Inquiries}

Inquiries are a series of actions of investigators to seek and find an event that is suspected of being a criminal act to determine whether or not inquiries can be carried out according to the method regulated in the Act. The act of inquiries to determine whether an event is a criminal

\footnotetext{
13 Ahmad M. Ridwan and Elis Herlina, "Tinjauan Yuridis Mengenai Akun Media Sosial Yang Melakukan Endorsement Judi Online (Online Gambling) Dihubungkan Dengan Undang- Undang Nomor 19 Tahun 2016 Tentang Perubahan Atas Undang-Undang Nomor 11 Tahun 2008 Tentang Informasi Dan Transaksi Elektronik," Jurnal Pemuliaan Hukum 1, no. $2 \quad$ (October $27, \quad 2020$ ): $13-20$, http://103.66.199.204/index.php/Pemuliaan/article/view/1001/681.

14 Muhammad Fauzi. Hernanda Ramdhani, “Otoritas Negara Dalam Penegakan Hukum Terhadap Pemberantasan Situs Judi Online Di Indonesia," Lex Suprema 2, no. 2 (December 2, 2020): 66-81, https://jurnal.law.unibabpn.ac.id/index.php/lexsuprema/article/view/387.

${ }^{15}$ Muthmainnah Muthmainnah, "Kendala-Kendala Penyidikan Dalam Memperoleh Alat Bukti Tindak Pidana Perjudian Bola Melalui Internet (Studi Di Polrestabes Surabaya).," Jurnal Mahasiswa Fakultas Hukum Universitas Brawijaya, 2014, 7, https://media.neliti.com/media/publications/35069-ID-kendala-kendalapenyidikan-dalam-memperoleh-alat-bukti-tindak-pidana-perjudian-b.pdf.

${ }^{16}$ Interview with the VC Committee for the Criminal Investigation Unit of the Bandar Lampung Police, 28 November 2018.

17 Interview with the VC Committee for the Criminal Investigation Unit of the Bandar Lampung Police, 28 November 2018.
} 
event is an obligation for the competent authority when receiving a report from the public as referred to in Article 102 Paragraph (1) of the Criminal Procedure Code: "Investigators who are aware, receive reports or complaints about the occurrence of an event that is reasonably suspected to be a criminal act are obliged to immediately take the necessary investigative actions." In carrying out the process of investigating online gambling crimes, the Bandar Lampung Police collaborate with the Resort Police, Polsek, Lampung Police, and Police Headquarters to make it easier to obtain information that can support catching perpetrators of online gambling network cases. The process of inquiries into online gambling crimes requires the police to conduct inquiries via the internet by browsing websites related to soccer gambling sites. Many websites on the internet are a platform for online soccer gambling: www.sbobet.com, www.m88.com, www.ibcbet.com, www.kakakdewa.com, and www.39bet.com. The police are required to search, observe, track, and analyze whether the crime actually exists and is included in the scope of the crime of gambling through the internet or only includes the crime of ordinary gambling.

\section{c. Conducting Investigation}

Investigations aim to obtain evidence that sheds light on finding the suspect of online gamblers. ${ }^{18}$ Investigators can establish a person as an online gambling suspect; however, if all the conditions as a suspect have been met, of course, with valid evidence. The method used to prevent gambling crimes, according to Eko Wijaya as VC Committee Satreskrim Polresta Bandar Lampung, is to prove the existence of online gambling activity is to disguise (undercover) which deliberately participates in running gambling through the internet to trap the online gambling perpetrators, by registering a member to the available gambling site admin to get a username to participate in the game in question. If you already have a username, the admin will provide instructions for following the game and communicating about game procedures. Therefore, to transact between gamblers with gambling managers, they also use bank transaction services with internet media. ${ }^{19}$

In addition to using the internet to establish member relationships, the online gambling site admin uses a certain number through a cellular phone used between members. The perpetrators of online gambling in conducting transactions usually do not meet directly with the members, usually done by tracking the phone and then transferring an agreed amount of money through a predetermined bank and from this method, the investigator gets evidence in the form of a print out of the conversation between the perpetrator and the user, where the investigator obtains the evidence by impersonating the user, proof of money transfer receipt, and proof of SMS from the perpetrator. This is under Article 5 Paragraph (2) of the ITE Law, which reads: "Electronic Information and/or Electronic Documents and/or their printouts are valid legal evidence. Electronic Information and/or Electronic Documents and/or their printed results as referred to in Paragraph (1) is an extension of valid evidence in accordance with the applicable procedural law in Indonesia."

The perpetrators can also participate in direct transactions. This is why investigators would trap. Then the investigator's next step is to technically prove the act. Interviews with Criminal Investigation investigators of the Bandar Lampung Police showed that evidence usually found in searching and collecting (internet) gambling evidence are mobile phones, laptops, modems, accounts, M-Banking, and ATM cards. Usually, most of the perpetrators throw away their savings books because they are used as fictitious accounts. In addition, the perpetrators also make transactions via e-mail to transfer data. In this case, the perpetrators usually do not tell

18 Said Munawar, "KEBIJAKAN PENEGAKAN HUKUM PIDANA TERHADAP PERJUDIAN," WIDYA PRANATA HUKUM JURNAL 1, no. 1 (March 26, 2019): http://ojs.widyamataram.ac.id/index.php/pranata/article/view/87.

19 Interview with the VC Committee for the Criminal Investigation Unit of the Bandar Lampung Police, 28 November 2018. 
the e-mail password so that investigators coordinate regarding e-mail code breaking with the National Police Headquarter. ${ }^{20}$

When investigators are sure of the perpetrator, they will hold a case title meeting in advance to plan an arrest. Before making an arrest, there are formal requirements that Police investigators must meet before making an arrest. The conditions are written in Article 43 Paragraph (6) of the ITE Law, which states: "In the case of making arrests and detentions, investigators through the public prosecutor are obliged to request a determination from the chairman of the local district court within twenty-four hours." As for the evidence, the National Police may use electronic evidence and/or printed documents or electronic information as an extension of evidence as referred to in Article 5 Paragraph (2) of the ITE Law, in addition to other conventional evidence by the Criminal Procedure Code.

\section{d. Arrest}

Following Article 1 number 20 of the Criminal Procedure Code, that arrest is an investigator's act in the form of temporary restraint of the freedom of a suspect or defendant if there is sufficient evidence for investigation or prosecution and or trial in matters and according to the method regulated by law. The arrest of online gambling perpetrators is carried out after sufficient initial evidence exists. As stipulated in the Regulation of the National Police Chief No. 14 of 2012 concerning Management of Criminal Investigations, that sufficient preliminary evidence is the information and data contained in two of them: police reports, police investigation report at the crime scene, reports on the results of the investigation, statements of witnesses or experts and evidence. The arrests made in online gambling from interviews with Bandar Lampung Police Investigators were made after receiving reports from members of the public and undercover to trap online gambling perpetrators. ${ }^{21}$

\section{- Search and Foreclosure}

Under the provisions of Article 33 Paragraph (1) of the Criminal Procedure Code, a search must be carried out with the Head of the District Court's permission. Under normal circumstances, searches must first obtain permission from the Head of the District Court. The search is urgent, considering that any procrastination will increase online gambling players. The search is then carried out first by obtaining a permit from the Head of the District Court. Ronald explained that a search could be carried out after the arrest. Confiscation under Article 38 of the Criminal Procedure Code must be with the permission of the Head of the local District Court. The opposite applies if, in an urgent situation, confiscation can be carried out without first obtaining permission from the Head of the District Court. ${ }^{22}$ The foreclosure is carried out before obtaining permission from the Head of the District Court. Further examination of the evidence can be carried out immediately, considering that the evidence obtained from online gambling actors is very easy to destroy. Evidence usually obtained from the confiscation of online soccer gambling in the form of cellphones, laptops, modems, accounts, checking accounts, M-Banking, and ATM cards.

\section{- Detention}

Whereas based on Article 21 Paragraph (1) of the Criminal Procedure Code, investigators have three grounds to make detentions. The basis is juridical; detention can only be carried out against perpetrators of criminal acts punishable by imprisonment for more than five years. In addition, detention can also be carried out against perpetrators of criminal acts even if the punishment is less than five years. The Articles of criminal Act significantly

\footnotetext{
${ }^{20}$ Interview with the VC Committee for the Criminal Investigation Unit of the Bandar Lampung Police, 28 November 2018.

${ }^{21}$ Interview with the VC Committee for the Criminal Investigation Unit of the Bandar Lampung Police, 28 November 2018.

${ }^{22}$ Interview with the VC Committee for the Criminal Investigation Unit of the Bandar Lampung Police, 28 November 2018.
} 
affect the interests of the community. The basis for concern is that it emphasizes the need for detention because it is feared that the perpetrators will run away, damage or lose evidence, or fear repeat the crime.

In addition to the above basics, detention must meet the requirements of the law as stated in Article 21 Paragraph (1) of the Criminal Procedure Code, namely: a suspect or defendant is strongly suspected of being the perpetrator of the crime in question, and the strong suspicion is based on sufficient evidence. According to the information from the Bandar Lampung Police Investigator, the detention was carried out because it fulfilled the three elements. First, the juridical element, namely, Article 45 Paragraph (1) of the ITE Law: "Everyone who fulfills the elements as referred to in Article 27 Paragraph (1), Paragraph (2), Paragraph (3), or Paragraph (4) shall be sentenced to a maximum imprisonment of 6 (six) years and/or a maximum fine of Rp. 100.000.000,00 (one billion rupiah)."

The legal sanction given to the perpetrator proven to have committed a crime of gambling via the internet is 6 (six) years in prison. Second, the element of destroying and eliminating evidence. Given the evidence in the crime of online soccer gambling, it is effortless for the perpetrators to remove them. Third, the detention of the perpetrator has fulfilled the legal requirements contained in Article 21 Paragraph (1) of the Criminal Procedure Code, which is strongly suspected of being the perpetrator of a criminal act of online soccer gambling, and the suspicion is based on sufficient evidence, as stated in the confiscation section above.

\section{- Delegation of Case Files and Suspects to the Prosecutor}

The police take the final stage in dealing with gambling crimes via the internet, namely by transferring case files along with evidence in the form of electronic evidence and electronic devices used by suspects and suspects or perpetrators of gambling crimes via the internet to the local District Attorney. The following are the stages of delegating cases to the prosecutor's office:

a. Complete Necessary Administration. The initial stage is before the case goes to the local prosecutor. Bandar Lampung police investigators must first complete the necessary administration in filings, such as minutes of arrest, minutes of detention, minutes of detention extension, minutes of foreclosure, resume of online football gambling, table of contents, and file cover.

b. Delivery of Case Files to Bandar Lampung District Attorney (Phase I). After all the administrative requirements in the filing are declared complete by the police, the case file will be sent to the Bandar Lampung District Prosecutor's Office, which the Prosecutor's Office will re-examine for its completeness.

c. The Prosecutor's Office Examines the Case File Completion. At this stage, the Bandar Lampung District Attorney examines the investigation's result in the file of the Bandar Lampung Police. After examining the case file for 14 days, the prosecutor is obliged to notify the case file examination result to the investigator or, often referred to as P.21results of the investigation have been declared complete by the prosecutor (P.18/P.19). The results of the investigation are not complete, accompanied by instructions from the prosecutor.

d. Transfer of Suspect and Evidence to the. This is the last stage in handling football gambling crimes via the internet, namely the transfer of suspects and evidence to the prosecutor's office if the case file submitted has been declared complete by the prosecutor's office (P.21). The submission of the suspect and evidence to the prosecutor's office signifies that the duties and authorities of investigators in gambling cases via the internet have been declared completed. 
Regarding online gambling investigations, the investigation mechanism is also the same as described above. Online gambling investigations begin with receiving complaints from the public. Followed by an investigation to verify whether the report can be followed up or not. If it can be followed up, then the case will be investigated. In investigating cases of online gambling crimes, there are also forced efforts in the form of arrests, detentions, searches, and confiscations, followed by the transfer of case files to the prosecutor's office. The weak mechanism for handling online gambling cases by the Judicial Sub-unit of the VC Sat. Reskrim Polresta Bandar Lampung lies in the beginning phase of the investigators themselves and community reports. This means that investigators here are passive. They only receive reports and then move on to carry out further legal procedures.

\section{Obstacles in Law Enforcement against Online Gambling Crimes in Bandar Lampung}

The process of proving the crime of gambling through the internet in court requires a technical approach because the evidence found can be in the form of electronic evidence that is still not recognized by the Criminal Code Procedure or Kitab Undang-Undang Hukum Acara Pidana (KUHAP). ${ }^{23}$ Therefore, it still has to be supported by expert testimony to be accepted in court. Investigators of the Subunit VC Satreskrim Polresta Bandar Lampung encountered obstacles in conducting investigations and investigations of online gambling crimes, which consisted of internal and external constraints. It is also necessary to know what are the weaknesses of the ITE Law are proving acts. ${ }^{24}$ It is also necessary to know the weaknesses of the ITE Law is proving online gambling crimes. The discussion can be described below.

\section{a. Weaknesses of the ITE Law in Proving Online Gambling Crimes}

The application of Article 303 of the Criminal Code for criminal acts of internet gambling makes the verification process difficult because the Criminal Code does not regulate elements containing information technology. In contrast, in the case of internet gambling, everything is done through internet media. Meanwhile, Article 27 Paragraph (2 and Article 45 Paragraph (1) of the ITE Law are not applied to the above cases due to the investigation procedures in Article 43 Paragraph (6) of the ITE Law, which is challenging to implement. Which requires investigators to make arrests and detentions through the public prosecutor requesting an appointment from the Head of the local District Court within 1x24 hours (one time twenty-four hours). It is not possible to do this. So the Sub-Directorate of VC Satreskrim Polresta Bandar Lampung as an investigator, was forced to use the instrument of Article 303 of the Criminal Code to handle internet gambling.

The proof is fundamental in the examination of cases in court. ${ }^{25}$ The proof is provisions that contain outlines and guidelines on ways that are legalized by law to prove the guilt charged to the defendant, through evidence that is legalized by law for further use by the judge in proving the defendant's guilt. ${ }^{26}$ Therefore, judges cannot use evidence contrary to the law because the truth of a decision must be tested with legally valid evidence and has the power of proof attached to any evidence found. In addition to evidence, evidence is also a vital thing in proving a crime, including internet gambling. ${ }^{27}$ The presence of internet gambling must be proven based on evidence approved by law. Talking about proof of gambling via the internet cannot be separated from the provisions regarding evidence regulated in the ITE Law. Article

\footnotetext{
23 Eliasta Ketaren, "Cybercrime, Cyber Space, Dan Cyber Law," Jurnal TIMES 5, no. 2 (2016): 35-42, https://ejournal.stmik-time.ac.id/index.php/jurnalTIMES/article/view/556.

${ }^{24}$ Edmon Makarim, Kompilasi Hukum Telematika (Jakarta: Raja Grafindo, 2004): 385.

${ }^{25}$ Ach. Tahir, Cyber Crime (Akar Masalah, Solusi Dan Penanggulangan) (Yogyakarta: Suka Press, 2011): 3.

${ }^{26}$ Aguita Bintang Murtika Sari, "PRAKTEK PERJUDIAN ONLINE SEBAGAI TINDAK PIDANA ASAL DARI TINDAK PIDANA PENCUCIAN UANG (STUDI PUTUSAN NO.1132/PID.B/2014/PN.JKT UTR)," Jurnal Hukum Pidana Dan Penanggulangan Kejahatan 7, no. 1 (January 2, 2018): 41-51, http://www.ejurnal.com/2013/12/pengertian-tindak-.

${ }^{27}$ Soerjono Soekanto, Pengantar Penelitian Hukum, 3rd ed. (Jakarta: UI Press, 2006): 277.
} 
5 Paragraph (1) of the ITE Law states that "Electronic information and/or electronic documents and/or their printed results are legal evidence".

Article 1 number 1 of the ITE Law stated: "Electronic information is one or a set of electronic data, including but not limited to writing, sound, pictures, maps, designs, photographs, Electronic Data Interchange (EDI), electronic mail (electronic mail), telegram, telex, telecopy, or the like, processed letters, signs, numbers, access codes, symbols or perforations that have meaning or can be understood by people who are able to understand them". Meanwhile, Article 1 point 4 of the ITE Law states that what is meant by: "Electronic document is any electronic information that is created, forwarded, sent, received or stored in analog, digital, electromagnetic, optical or similar forms, which can be viewed, displayed and/or by means of a computer or electronic system, including but not limited to written, sound, pictures, maps, designs, photographs or the like, letters, signs, numbers, access codes, symbols or processed perforations that have meaning or can be understood by people who can understand it." When examined, the website of the gambling organizer through the internet and the E-mail of the gambling participants and SMS is part of the electronic information. It can be categorized as one of the legal pieces of evidence. The evidence can be obtained through searches and confiscations that investigators can carry out. Based on Article 43 Paragraph (3) of the ITE Law, it is stated that the search and/or confiscation of electronic systems, as well as the arrest and detention of Cyber Crime perpetrators, must be carried out with the permission of the Head of the local District Court within 1x24 hours (one time twenty-four hours). Binsar explained that the above provisions are a complicated matter to be realized because it is not possible to obtain a permit from the Head of the local District Court to do this in such a short time. In addition, until now, there is no Indonesian Government Regulation on the ITE Law, including regarding the conduct of searches, confiscations, arrests, and detention of suspects in gambling cases through the internet. ${ }^{28}$

In addition to the weakness in fulfilling the electronic evidence, the weakness of the ITE Law is that criminal sanctions against online gambling (vide: Article 45 of the ITE Law) are lower than the threat of criminal sanctions in Article 303 of the Criminal Code. Article 45 of the ITE Law has criminal sanctions with a penalty of 6 years, while Article 303 of the Criminal Code is 10 years. It is related to Article 63 Paragraph (1) of the Criminal Code that: "If an act falls under more than one criminal law, only one of those rules is imposed; if they are different, the one imposed which contains the most severe principal criminal threat." Therefore, departing from this provision, the investigators of the Subunit VC Sat. Reskrim Polresta Bandar Lampung has been correct in applying Article 303 of the Criminal Code against online gamblers because the criminal sanctions are heavier than Article 45 of the ITE Law. Article 63 Paragraph (2) of the Criminal Code states that: "If an act is included in a general criminal code, it is also regulated in a special criminal rule, then only the specific one is applied." Associated with online gambling law enforcement that has been carried out by the VC Sat. Reskrim Sat. Reskrim Bandar Lampung Police Investigator who applies Article 303 of the Criminal Code rather than Article 45 of the ITE Law is a violation of this provision.

\section{b. The Longer Detention Period for Online Gambling Crimes in the Criminal Code Instruments than the Gambling Control Act}

Too much workload for investigators in the Subunit Vice Control Satreskrim Polresta Bandar Lampung causes investigators to take a long time to process case files. Investigators are not focused on dealing with cybercrime, especially online gambling. Their concentration is divided into existing cases that sometimes deviate far, for example, embezzlement, fraud, land, and buildings. The specifications of the Satreskrim Polresta Bandar Lampung have been divided, but because police reports from the community are diverse and many outside of Cyber Crime,

${ }^{28}$ Interview with the VC Committee for the Criminal Investigation Unit of the Bandar Lampung Police, 28 November 2018. 
so that it is ideal for excessive police handling, and this has implications for the speed of handling cases, both those reported by the public and those found by the investigator alone. ${ }^{29}$

Therefore, investigators often use Article 303 of the Criminal Code rather than Article 45 of the ITE Law. Criminal sanctions in Article 303 of the Criminal Code for online gambling are threatened with a maximum criminal sanction of 10 years in prison, while Article 45 of the ITE Law is a maximum of 6 years. This causes a difference in holding time. ${ }^{30}$ If the investigator uses Article 303 of the Criminal Code, the investigator gets a maximum detention time of 120 days. 122 Meanwhile, if using Article 45 of the ITE Law, the investigator only gets a detention time of 60 days. So, with such a high filing workload, investigators need a longer detention time so that gambling cases can be adequately handled. However, this causes Article 45 of the ITE Law to not be applied as the main article. The principle of lex specialis derogat lex generali requires investigators to apply the instruments of the ITE Law rather than the Criminal Code. ${ }^{31}$ c. Lack of Investigators' Awareness in Information Technology

Several investigators from the Bandar Lampung Police have not yet mastered Information Technology, and there is no internet socialization at the Bandar Lampung Police. Given the importance of supporting human resources to support the smooth running of an investigation, investigation, and arrest process. Based on the investigator's statement, only a few personnel and not many investigators at the Bandar Lampung Police understand the field of information technology. This is not balanced with the existing cases, along with the rampant crime of gambling over the internet, which can still happen at any time in society.

There are still many cases of soccer gambling via the internet that have not been revealed or the cessation of investigators due to a lack of experts at the Bandar Lampung Police Office, so that the government needs to think about providing IT training to police officers, both at each Polres and Polsek, specifically the VC Satreskrim Sub-unit of the Bandar Lampung Police. Investigators still do not understand the difference between handling general criminal cases and Cyber Crime cases. For example, treat both witnesses and evidence technically because Cyber Crime is processed and explicitly treated, unlike other evidence of criminal acts. Like software, when the investigator turns off and unplugs the laptop or computer that is used, the evidence is lost and how to crack the codes that have been set in such a way by the perpetrator so that when the investigator tries to open the codes, the data displayed has changed. ${ }^{32}$

This tracking and investigation process is carried out manually by tracing existing data; investigators use no sophisticated tools at the Bandar Lampung Police. Sophisticated tools are only found at the Indonesian National Police Headquarters (Police Headquarters). and the Lampung Regional Police. However, investigators are still allowed to use these sophisticated tools when the situation is urgent. The licensing process is very calculated, considering that these sophisticated tools reach billions of rupiah. The tool can track the direction of the signal. However, according to Eko Wijaya, so far, all gambling cases via the internet how to handle it is to do it manually, collaborate with relevant agencies and browse websites related to gambling via the internet, and have never borrowed a tool. The sophisticated. So the police must observe and research in tracking suspects so that they are not misdirected at the time of arrest and collection of evidence.

Sites on the internet that serve online gambling, soccer gambling that has not been controlled has made soccer gambling through the internet increasingly widespread in the

\footnotetext{
${ }^{29}$ Interview with the VC Committee for the Criminal Investigation Unit of the Bandar Lampung Police, 28 November 2018.

${ }^{30}$ Achmadi Achmadi, "Penegakan Hukum Pidana Terhadap Praktek Perjudian Dalam Ritual Tiwah Di Kabupaten Kapuas," Anterior Jurnal 15, no. 2 (June 1, 2016): 180-88, https://doi.org/10.33084/anterior.v15i2.54.

31 Interview with the VC Committee for the Criminal Investigation Unit of the Bandar Lampung Police, 28 November 2018.

${ }^{32}$ Interview with the VC Committee for the Criminal Investigation Unit of the Bandar Lampung Police, 28 November 2018.
} 
community because of the ease of access. ${ }^{33}$ Perpetrators of soccer gambling crimes follow this through the internet, which is increasingly sophisticated, in operating soccer gambling websites. To uncover gambling crimes via the internet at the Bandar Lampung Police, you must ask the Lampung Regional Police for help to track the whereabouts of the perpetrators. This request for assistance is due to the lack of complete supporting equipment. So that investigators have to wait for the information given to the Lampung Police, and if the Lampung Police do not provide any information, then the online gambling crime cannot be revealed by the VC Satreskrim Criminal Investigation Unit investigators until the Lampung Police provide information on the whereabouts of the perpetrators so that this affects the speed of handling cases.

The Bandar Lampung Police Station should have adequate facilities and infrastructure and supporting equipment to uncover the perpetrators; thus, this has been done manually and by chance in catching the perpetrators. The most frequent obstacle in the investigation process is the address registered on the identity of a fictitious suspect because perpetrators easily make ID cards with fake names and addresses. In acting, the perpetrator does not stay in one place, using sophisticated equipment or gadgets. The perpetrator performs his action anywhere, and also, the perpetrator eliminates traces by removing the perpetrator's phone number so that his position cannot be traced. If the perpetrator's address can still be traced and his whereabouts can still be traced, then the Bandar Lampung Police Satreskrim Subunit VC Officer will continue to look for it. ${ }^{34}$

\section{d. Use of Electronic Evidence Requires Expert Information}

The difficulty of obtaining evidence in soccer gambling cases via the internet has resulted in the investigation and investigation process being often stopped. Online gambling is included in the Cyber Crime case, so the evidence to carry out the investigation process is only in the form of electronic information and electronic documents. ${ }^{35}$ Because the crime scene (TKP) occurs on the internet, investigators study and observe using the internet; if necessary, investigators collaborate with other agencies involved in soccer gambling. If there is insufficient evidence in the case, the investigation process is terminated. According to Eko Wijaya as the VC Subnit Committee of the Bandar Lampung Police Satreskrim, the obstacles that are often experienced in the field during the investigation process, namely: The use of electronic evidence in the application of the ITE Law on online gambling, causes the need for expert testimony to explain the electronic evidence. Meanwhile, the budget for investigating gambling crimes is not budgeted, so that investigators must be independent. This causes investigators to only apply Article 303 of the Criminal Code in online gambling cases.

\section{Conclusion}

Based on the results of the discussion and research, it can be concluded that law enforcement against online gambling crimes in Bandar Lampung City is carried out by applying the instrument of Article 303 of the Criminal Code rather than Article 27 Paragraph (2) Jo. Article 45 of the ITE Law. Efforts are made through legal norms themselves in real terms to guide behaviour in legal relations and social and state life. Then the inhibiting factor in law enforcement against online gambling crimes in Bandar Lampung is the criminal sanctions

\footnotetext{
${ }^{33}$ Aniza Lakoro, Lisnawaty Badu, and Nuvazria Achir, "Lemahnya Kepolisian Dalam Penanganan Tindak Pidana Perjudian Togel Online," JURNAL LEGALITAS 13, no. 01 (April 26, 2020): 31-50, https://doi.org/10.33756/JELTA.V13I01.7304.

34 Interview with the VC Committee for the Criminal Investigation Unit of the Bandar Lampung Police, 28 November 2018.

${ }^{35}$ Rischa. Oktavyani, "PENEGAKAN HUKUM TERHADAP PELAKU YANG DISTRIBUSIKAN DOKUMEN ELEKTRONIK YANG MEMILIKI MUATAN PERJUDIAN Di Wilayah Hukum Kepolisian Daerah Kalimantan Timur," LEX SUPREMA Jurnal Ilmu Hukum 2, no. 1 (August 8, 2020): 1-13, https://jurnal.law.unibabpn.ac.id/index.php/lexsuprema/article/view/313.
} 
against online gambling based on Article 45 of the ITE Law, which is lower than the threat of criminal sanctions in Article 303 of the Criminal Code, the difference in detention time. Article 303 of the Criminal Code maximum detention time is 120 days.

Meanwhile, if using Article 45 of the ITE Law, investigators only get a detention time of 60 days. However, this causes Article 45 of the ITE Law to not be applied as the main article. The principle of lex specialis derogat lege generali requires investigators to apply the instruments of the ITE Law rather than the Criminal Code, the lack of understanding and mastery of investigators in the field of information technology is not balanced with the development of the ability of online gamblers and the use of electronic evidence requires expert testimony. The suggestion put forward by the author in this matter is that the application of the Criminal Code and the ITE Law in online gambling cases must prioritize the principle of lex specialis derogat legi generalis. This means that online gambling must apply the ITE Law, not the Criminal Code. Conducting information technology guidance training for the Criminal Investigation Unit of the Bandar Lampung Police.

\section{Bibliography}

\section{A. Book}

Tahir, Ach. Cyber Crime (Akar Masalah, Solusi Dan Penanggulangan). Yogyakarta: Suka Press, 2011.

Makarim, Edmon. Kompilasi Hukum Telematika. Jakarta: Raja Grafindo, 2004.

\section{B. Journal}

Achmadi, Achmadi. "Penegakan Hukum Pidana Terhadap Praktek Perjudian Dalam Ritual Tiwah Di Kabupaten Kapuas." Anterior Jurnal 15, no. 2 (June 1, 2016): 180-88. https://doi.org/10.33084/anterior.v15i2.54.

Alikhademi, Kiana, Emma Drobina, Diandra Prioleau, Brianna Richardson, Duncan Purves, and Juan E. Gilbert. "A Review of Predictive Policing from the Perspective of Fairness." Artificial Intelligence and Law, April 15, 2021, 1-17. https://doi.org/10.1007/s10506-02109286-4.

Bintang Murtika Sari, Aguita. "PRAKTEK PERJUDIAN ONLINE SEBAGAI TINDAK PIDANA ASAL DARI TINDAK PIDANA PENCUCIAN UANG (STUDI PUTUSAN NO.1132/PID.B/2014/PN.JKT UTR)." Jurnal Hukum Pidana Dan Penanggulangan Kejahatan 7, no. 1 (January 2, 2018): 41-51. http://www.ejurnal.com/2013/12/pengertian-tindak-.

Braga, Anthony A., Lisa M. Barao, Gregory M. Zimmerman, Stephen Douglas, and Keller Sheppard. "Measuring the Direct and Spillover Effects of Body Worn Cameras on the Civility of Police-Citizen Encounters and Police Work Activities." Journal of Quantitative Criminology 36, no. 4 (December 1, 2020): 851-76. https://doi.org/10.1007/s10940-019-09434-9.

Caserta, Salvatore. "The Sociology of the Legal Profession in the Digital Age." International Journal of the Legal Profession, 2021, 1-16. https://doi.org/10.1080/09695958.2021.1920417.

Haryanti, Wella. "Penegakan Hukum Oleh Satreskrim Kepolisian Resort Kota Padang Terhadap Pelaku Tindak Pidana Perjudian Yang Dilakukan Oleh Remaja." Article $\begin{array}{lllll}\text { Wisudawan } & 12, & \text { no. } & 2020): & \text { 27-37. }\end{array}$ https://www.ejurnal.bunghatta.ac.id/index.php/JFH/article/view/18198.

Hernanda Ramdhani, Muhammad Fauzi. "Otoritas Negara Dalam Penegakan Hukum Terhadap Pemberantasan Situs Judi Online Di Indonesia.” Lex Suprema 2, no. 2 (December 2, 2020): 
66-81. https://jurnal.law.uniba-bpn.ac.id/index.php/lexsuprema/article/view/387.

Isnaini, Enik. "TINJAUAN YURIDIS NORMATIF PERJUDIAN ONLINE MENURUT HUKUM POSITIF DI INDONESIA.” Jurnal Independent 5, no. 1 (June 1, 2017): 23. https://doi.org/10.30736/ji.v5i1.61.

Ketaren, Eliasta. "Cybercrime, Cyber Space, Dan Cyber Law.” Jurnal TIMES 5, no. 2 (2016): 35-42. https://ejournal.stmik-time.ac.id/index.php/jurnalTIMES/article/view/556.

Lakoro, Aniza, Lisnawaty Badu, and Nuvazria Achir. "Lemahnya Kepolisian Dalam Penanganan Tindak Pidana Perjudian Togel Online." JURNAL LEGALITAS 13, no. 01 (April 26, 2020): 31-50. https://doi.org/10.33756/JELTA.V13I01.7304.

Manalu, Hendri Saputra. "Penegakan Hukum Terhadap Pelaku Tindak Pidana Perjudian Online (Studi Putusan Pengadilan Negeri Medan Nomor 870/Pid.B/2018/PN.Mdn).” Journal of Education, Humaniora and Social Sciences (JEHSS) 2, no. 2 (December 19, 2019): 428539. https://doi.org/10.34007/jehss.v2i2.102.

. "Penegakan Hukum Terhadap Pelaku Tindak Pidana Perjudian Online Penegakan Hukum Terhadap Pelaku Tindak Pidana Perjudian Online (Studi Putusan Pengadilan Negeri Medan Nomor 870/Pid.B/2018/PN.Mdn)." Journal of Education, Humaniora and Social Sciences (JEHSS) 2, no. 2 (September 17, 2019): 428-539. https://ocs.unud.ac.id/index.php/kerthawicara/article/view/46728.

Mańko, Rafał. "Judicial Decision-Making, Ideology and the Political: Towards an Agonistic Theory of Adjudication." Law and Critique, March 30, 2021, 1-20. https://doi.org/10.1007/s10978-021-09288-w.

Munawar, Said. "KEBIJAKAN PENEGAKAN HUKUM PIDANA TERHADAP PERJUDIAN." WIDYA PRANATA HUKUM JURNAL 1, no. 1 (March 26, 2019): 1-18. http://ojs.widyamataram.ac.id/index.php/pranata/article/view/87.

Muthmainnah, Muthmainnah. "Kendala-Kendala Penyidikan Dalam Memperoleh Alat Bukti Tindak Pidana Perjudian Bola Melalui Internet (Studi Di Polrestabes Surabaya)." Jurnal Mahasiswa Fakultas Hukum Universitas Brawijaya, 2014, 7. https://media.neliti.com/media/publications/35069-ID-kendala-kendala-penyidikandalam-memperoleh-alat-bukti-tindak-pidana-perjudian-b.pdf.

Oktavyani, Rischa. "PENEGAKAN HUKUM TERHADAP PELAKU YANG DISTRIBUSIKAN DOKUMEN ELEKTRONIK YANG MEMILIKI MUATAN PERJUDIAN Di Wilayah Hukum Kepolisian Daerah Kalimantan Timur." LEX SUPREMA Jurnal Ilmu Hukum 2, no. 1 (August 8, 2020): 1-13. https://jurnal.law.unibabpn.ac.id/index.php/lexsuprema/article/view/313.

Ridwan, Ahmad M., and Elis Herlina. "Tinjauan Yuridis Mengenai Akun Media Sosial Yang Melakukan Endorsement Judi Online (Online Gambling) Dihubungkan Dengan UndangUndang Nomor 19 Tahun 2016 Tentang Perubahan Atas Undang-Undang Nomor 11 Tahun 2008 Tentang Informasi Dan Transaksi Elektronik.” Jurnal Pemuliaan Hukum 1, no. 2 (October 27,2020$):$ 13-20. http://103.66.199.204/index.php/Pemuliaan/article/view/1001/681.

Safitri, Dian Eka. "PENEGAKAN HUKUM TERHADAP PELAKU PERJUDIAN ONLINE DI KOTA MAKASSAR.” Jurnal Magister Hukum ARGUMENTUM 7, no. 1 (April 1, 2020): 10. https://doi.org/10.24123/argu.v7i1.3014.

Sannyasa, Gede Darma, and I Ketut Mertha. "PENGATURAN TINDAK PIDANA PERJUDIAN DAN PERTANGGUNGJAWBAN PIDANA KORPORASI DALAM MICRO-TRANSACTION PADA GAME ONLINE." Kertha Semaya: Journal Ilmu Hukum 8, no. 9 (September 24, 2020): 1467-82. https://doi.org/10.24843/KS.2020.v08.i09.p14.

Sheppard, Keller G., Gregory M. Zimmerman, and Emma E. Fridel. "Examining the Relevance of Contextual Gun Ownership on Fatal Police Shootings." Justice Quarterly, May 24, 
2021, 1-23. https://doi.org/10.1080/07418825.2021.1922733.

Soekanto, Soerjono. Pengantar Penelitian Hukum,. 3rd ed. Jakarta: UI Press, 2006.

Tahir, Ach. Cyber Crime (Akar Masalah, Solusi Dan Penanggulangan). Yogyakarta: Suka Press, 2011.

\section{Regulation}

Law No. 7/1974 on Gambling Control.

Law No. 8/1981 on the Law of Criminal Procedure.

Law No. 11/2008 on Electronic Information and Transactions.

\section{Internet}

Alimuddin. "Aplikasi Pembaharuan Hukum Dalam Teori Socio Legal Studies.” Ditjen Badan Peradilan, 2004. www.badilag.net. 